\title{
DNA hybridization mechanism in an interfacial environment: What hides beneath first order $k\left(s^{-1}\right)$ kinetic constant?
}

\author{
M. Lazerges ${ }^{a, b, *}$, H. Perrot ${ }^{a, b}$, N. Rabehagasoa ${ }^{c}$, C. Compère ${ }^{c}$, C. Dreanno ${ }^{c}$, M. Mucio Pedroso ${ }^{d}$, \\ R.C. Faria ${ }^{d}$, P.R. Bueno ${ }^{e}$
}

\begin{abstract}
a CNRS, UPR 15, Laboratoire Interfaces et Systèmes Electrochimiques, 4 Place Jussieu, 75252 Paris, France
${ }^{\mathrm{b}}$ Université Pierre et Marie Curie, LISE, 4 Place Jussieu, 75252 Paris, France

c IFREMER, Centre de Brest, Service Interfaces et Capteurs, Z.I. Pointe du Diable, 29280 Plouzané, France

d Departamento de Química, Universidade Federal de São Carlos, CP 676, 13560-905, São Carlos, São Paulo, Brazil

e Instituto de Química, Departamento de Físico-Química, Universidade Estadual Paulista, CP 355, 14800-900, Araraquara, São Paulo, Brazil
\end{abstract}

*: Corresponding author : M. Lazerges, email address : mathieu.lazerges@univ-paris5.fr

\begin{abstract}
:
The scientific question addressed in this work is: what hides beneath first order kinetic constant $k\left(\mathrm{~s}^{-1}\right)$ measured for hybridization of a DNA target on a biosensor surface. Kinetics hybridization curves were established with a $27 \mathrm{MHz}$ quartz microbalance (9 MHz, third harmonic) biosensor, constituted of a 20base probe monolayer deposited on a gold covered quartz surface. Kinetics analysis, by a known twostep adsorption-hybridization mechanism, is well appropriate to fit properly hybridization kinetics curves, for complementary 20-base to 40-base targets over two concentration decades. It was found that the $K_{1}\left(\mathrm{M}^{-1}\right)$ adsorption constant, relevant to the first step, concerns an equilibrium between non hybridized targets and hybridized pre-complex and increases with DNA target length. It was established that $k_{2}\left(\mathrm{~s}^{-1}\right)$, relevant to irreversible formation of a stable duplex, varies in an opposite way to $K_{1}$ with DNA target length.
\end{abstract}

Keywords : Biosensors ; DNA ; Hybridization kinetics ; Quartz crystal microbalance 


\section{Introduction}

Nucleic acid hybridization mechanism was investigated on nitrocellulose membrane using an acoustic biosensor [1]. The integral hybridization kinetics is equal to:

$$
\ln (1-\eta)=-\mathrm{k} . \mathrm{t}
$$

where $\eta$ is the hybridization efficiency ratio, and $\mathrm{k}$, the first order rate kinetics constant, was reported equal to $8.0 .10^{-5} \mathrm{~s}^{-1}\left(65^{\circ} \mathrm{C}, 4000\right.$ bases target, $\left.3.10^{-9} \mathrm{M}\right)$. Secondary structure effects on hybridization kinetics where investigated recently with a fluorescent biosensor, designed by deposit of a thiol-labeled probe self-assembled monolayer onto a gold surface [2]. The kinetics law, obtained for DNA targets including secondary structure or not, is equal to:

$$
\ln (1-\eta)=-k_{\text {eff. C.t }}
$$

where $\mathrm{C}(\mathrm{M})$ is the target bulk concentration, and $\mathrm{k}_{\mathrm{eff}}\left(\mathrm{M}^{-1} \cdot \mathrm{s}^{-1}\right)$ is the effective hybridization first order kinetics constant. $\mathrm{k}_{\text {eff }}$ is equal to $1.2 .10^{6} \mathrm{M}^{-1} \cdot \mathrm{s}^{-1}$ for a target without secondary structure $\left(20^{\circ} \mathrm{C}, 25\right.$ bases $)$, and $2.10^{5} \mathrm{M}^{-1} \cdot \mathrm{s}^{-1}$ for a target including an airpin-like structure $\left(20^{\circ} \mathrm{C}, 25\right.$ bases). The kinetics law [E2] yield to [E1] for a constant bulk target concentration. The $\mathrm{k}_{\mathrm{eff}}$ value found for hybridization on nitrocellulose membrane [1], equal to $2.7 .10^{4} \mathrm{M}^{-1} \cdot \mathrm{s}^{-1}$ ( $65{ }^{\circ} \mathrm{C}, 4000$ bases), is lower due to the largest size of the target. Kinetics law [E2], taking into account both kinetics constant and bulk solution concentration, is relevant to a one-step surface hybridization mechanism (Figure 1):

$$
\mathrm{T}+\mathrm{P}_{\eta} \stackrel{\mathrm{k}_{\mathrm{eff}}}{\longrightarrow} \mathrm{TP}_{\eta}
$$

Figure 1. One-step surface hybridization mechanism.

T are target diffusing in bulk solution, $\mathrm{P}_{\eta}$ are single stranded probes grafted onto the biosensor surface and $\mathrm{TP}_{\eta}$ are hybridized probes. Most of the hybridization kinetics monitored on biosensors are well fitted with a first order kinetics [E2]. A mechanism including hybridization competition between two targets quoted 1 and 2 was reported [3]:

$$
\ln (1-\eta)=-\left(k 1_{\text {eff }}+k 2_{\text {eff }}(1-a)\right) \cdot C \cdot t
$$

Where a competetion parameter of hybridization between two targets. Nevertheless, one study report a second order rate, on a biosensor designed by chemical grafting of probes on fused 
silica optical fibers [4]. This difference was attributed to lateral interactions due to high probe surface density. The kinetics integral law is then equal to:

$$
\eta=t / t+k_{\text {eff }} \cdot C
$$

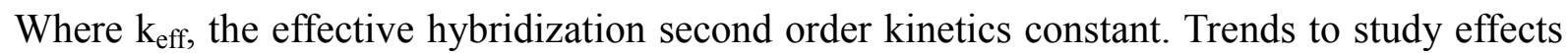
on hybridization kinetics in an interfacial environment are to use first order kinetics laws similar to [E2] (Figure 1). This equation is convenient to enlighten kinetics-target structure dependence. A two-step mechanism was reported to describe hybridization of nucleic acid on the surface of dispersed carbon nanotubes (Figure 2) [5].

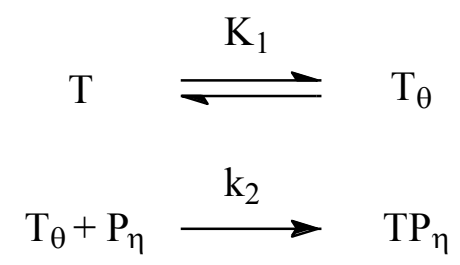

Figure 2. Two-steps surface hybridization mechanism.

A first rapid Langmuir adsorption step, consisting of non specific Langmuir physical adsorption of target $(T)$ onto the biosensor surface $\left(T_{\theta}\right)$. A second irreversible rate determining step, consisting on hybridization of a target diffusing on the sensor surface $\left(\mathrm{T}_{\theta}\right)$ with a grafted complementary probe $\left(\mathrm{P}_{\eta}\right)$, yielding to a stable duplex formation $\left(\mathrm{TP}_{\eta}\right)$. The kinetics integral law is given by (Annexe):

$$
\ln (1-\eta)=-\left(\mathrm{K}_{1} \cdot \mathrm{k}_{2} \cdot \mathrm{C} /\left(1+\mathrm{K}_{1} \cdot \mathrm{C}\right)\right) \cdot \mathrm{t}
$$

Where $\mathrm{K}_{1}$, the equilibrium constant of non specific adsorption, was found equal to $5.10^{7} \mathrm{M}^{-1}$, and first order kinetics constant $\mathrm{k}_{2}$, related to surface hybridization, was found equal to 5.57.10 $0^{-5} \mathrm{M}^{-1}\left(25^{\circ} \mathrm{C}, 25\right.$ bases target). This law is more general than [E2], and is equal to this last one for feeble target concentrations. $\mathrm{k}_{\mathrm{eff}}$ was in this case equal to $2.8 .10^{3} \mathrm{M}^{-1} \cdot \mathrm{s}^{-1}$. This value of $\mathrm{k}_{\mathrm{eff}}$, lower than those reported on biosensor constituted of probe self-assembled monolayers deposited onto solid substrate, is attribute to high activation hybridization barrier of nanostructures. The question addressed in this work is to establish if the to step mechanism observed for hybridization on nanoparticules is general, and can be used to describe hybridization in the case of a biosensor designed by self-assembled monolayer formation onto a gold surface. This problematic is investigated by analysis of hybridization kinetics, of DNAtargets of different length (10-bp to 45 -bp) over 2 target concentration decades, monitored with a $27 \mathrm{MHz}$ quartz crystal microbalance biosensor ( $9 \mathrm{MHz}$, third harmonic). 


\section{Experimental}

\subsection{Chemical and biochemical reagents}

Water is deionized and double distillated. $\mathrm{H}_{2} \mathrm{SO}_{4} 95 \%, \mathrm{H}_{2} \mathrm{O}_{2} 30 \%, \mathrm{NaOH}, \mathrm{HCl}, \mathrm{NaCl}$ and $1 \mathrm{M}$ HEPES buffer are from Sigma Aldrich (biochemical grade). DNA probe and targets synthesized by Eurogentec [6] are purified by chromatography, checked by MALDI-TOF analysis and dosed by UV optical density measurements. Sequences of disulfide labeled probe (P) and targets (T1 to $\underline{\mathrm{T} 6})$ are presented on table 1 .

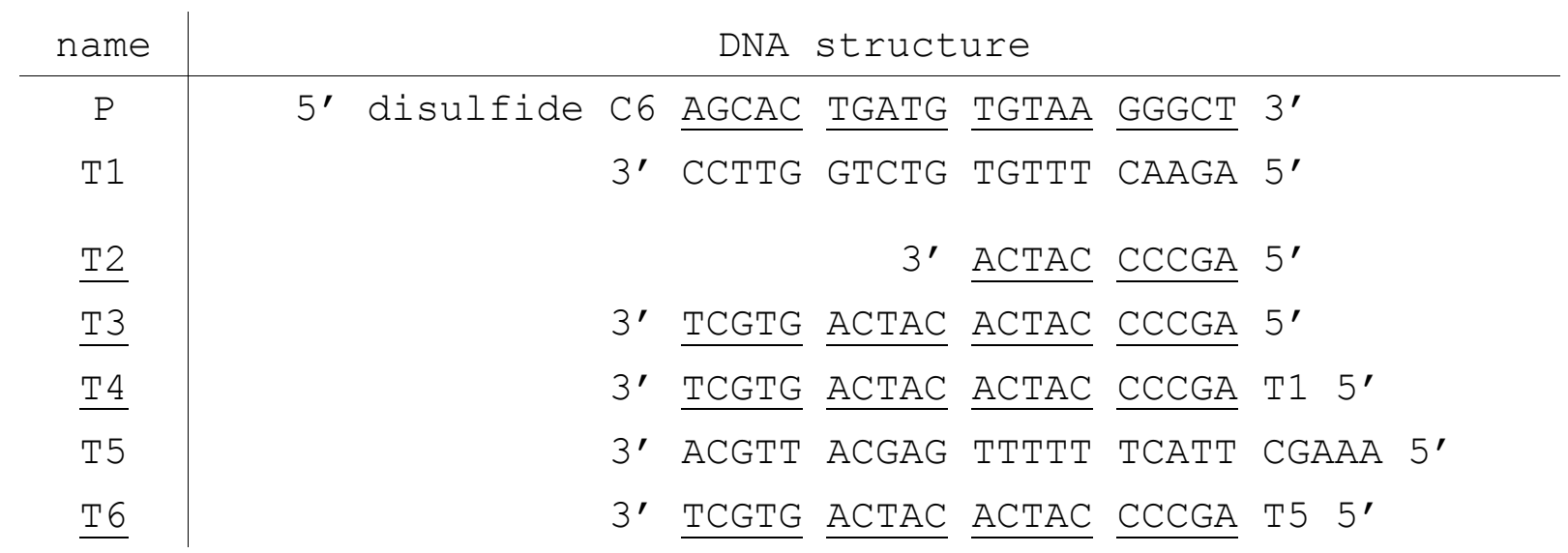

Table. 1. Structure of DNA probe (P) and DNA targets (T1 to $\underline{\mathrm{T} 6})$. Complementary probe-target sequences are underlined.

The sequence of the probe $(\mathrm{P})$ is a partial sequence of the gene encoding for the large ribosomal RNA sub-unit of Alexandrium minutum [7, 8], a toxic algae responsible of paralytic shellfish poisoning on American, Asian and European coastal waters [9].

\subsection{Buffers and solutions}

The solution for DNA grafting consists in $0.5 \mathrm{M} \mathrm{NaCl}$. Hybridization experiments are performed in optimized stringency condition [10]: the hybridization buffer is composed of 0.5 $\mathrm{M} \mathrm{NaCl}, 50 \mathrm{mM}$ HEPES, adjusted to $\mathrm{pH} 7.2$ with $1 \mathrm{M} \mathrm{NaOH}$. The regeneration step is carried out with $0.5 \mathrm{M} \mathrm{NaOH}, 3 \mathrm{M} \mathrm{NaCl}$ solution.

\subsection{QCM apparatus}

The resonator of the microbalance is a Matel-Fordhal France AT-cut planar quartz crystal, 14 $\mathrm{mm}$ in diameter, with a $9 \mathrm{MHz}$ nominal resonance frequency. Two identical gold electrodes, 
$2000 \AA$ thick and $5 \mathrm{~mm}$ in diameter, are deposited by evaporation techniques on both sides of piezoelectric quartz, with a $250 \AA$ chromium underlayer. The resonator is connected by a silver conducting paste, through wires, to a BNC connector. A home-made oscillator is designed to drive the crystal at $27 \mathrm{MHz}$, which corresponds to the third overtone of the quartz resonator. To improve the stability, all the electronic oscillator components are temperaturecontrolled by a Watlow heater monitor with stability better than $0.1{ }^{\circ} \mathrm{C}$. The crystal is mounted between two O-ring seals inserted in a home-made plexiglass cell. Only one face of the quartz is in contact with the solutions. The cell volume is $50 \mu \mathrm{L}$. The apparatus includes a Pharmacia micropump to assure a $50 \mu \mathrm{L} / \mathrm{min}$ constant flow of the solutions in the quartz cell. The frequency is measured with a PM 6685 frequency counter and recorded with a homemade $\mathrm{C}$ language software. The experiments are performed at $25 \pm 2{ }^{\circ} \mathrm{C}$.

\section{Results}

\subsection{Biosensor design, hybridization efficiency and regeneration}

The biosensor is designed by grafting the thiol-labeled probe $\mathrm{P}$ on the gold quartz surface of the microbalance via Au-S bonds. Probe grafting, selective target hybridization and biosensor regeneration, are monitored by frequency measurements (Figure 3-A).

A

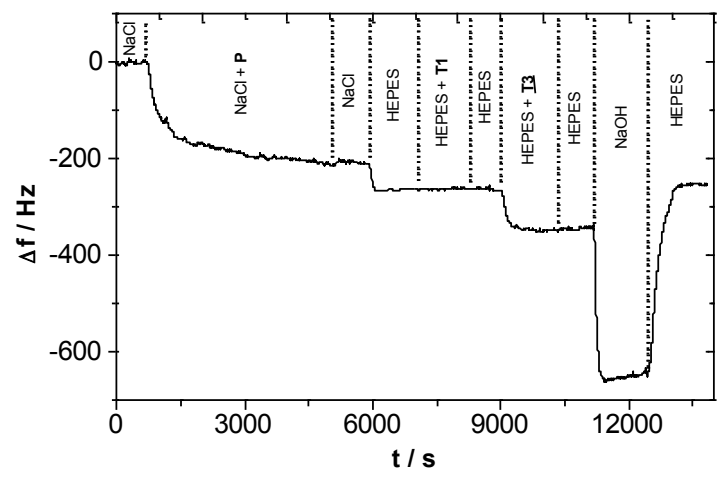

B

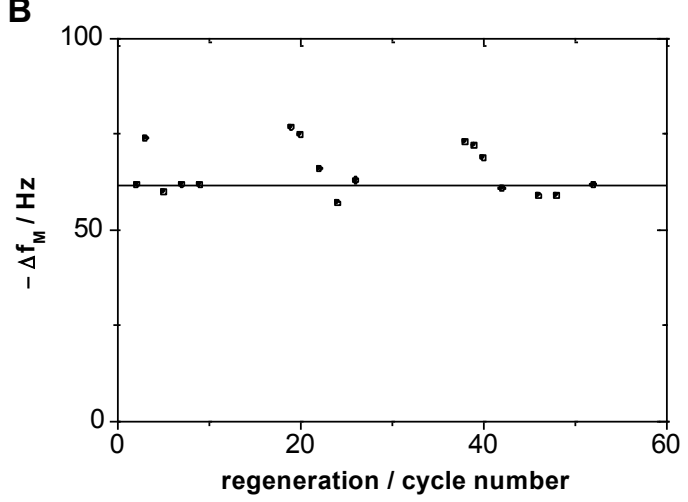

Figure 3. Biosensor response: frequency-time curve of probe grafting, target hybridization and biosensor regeneration (A). Hybridization frequency variation with number of biosensor regeneration cycles $(\mathrm{B})$.

A - $205 \mathrm{~Hz}$ frequency decrease is recorded during circulation of a probe P saline solution (3.2 $\mu \mathrm{M}, \mathrm{NaCl} 0.5 \mathrm{M})$. No frequency variations are observed during circulation of a saline solution $(\mathrm{NaCl} 0.5 \mathrm{M})$, indicating that DNA probes are irreversibly grafted to the sensor surface. The biosensor surface coverage $\tau(\%)$ with grafted probes is equal to: 


$$
\tau=100 \cdot\left|\Delta \mathrm{f}_{\mathrm{P}}\right| \cdot \mathrm{S}_{\mathrm{QCM}} \cdot \mathrm{N}_{\mathrm{A}} \cdot \mathrm{A}_{\mathrm{P}} / \mathrm{A}_{\mathrm{QCM}} \cdot \mathrm{M}_{\mathrm{P}}
$$

$\Delta \mathrm{f}_{\mathrm{P}}$ is the frequency change during probe grafting $(-205 \mathrm{~Hz}), \mathrm{S}_{\mathrm{QCM}}$ the experimental microbalance sensitivity $(350 \mathrm{pg} / \mathrm{Hz})[11], \mathrm{N}_{\mathrm{A}}$ the Avogadro constant $\left(6.023 .10^{23} \mathrm{~mol}^{-1}\right), \mathrm{A}_{\mathrm{P}}$ the average area of one grafted probe $\left(2.2 \mathrm{~nm}^{2}\right)[10], \mathrm{A}_{\mathrm{QCM}}$ the gold covered quartz detection surface $\left(0.2 \mathrm{~cm}^{2}\right)$ and $\mathrm{M}_{\mathrm{P}}$ the probe molecular weight $(6386 \mathrm{~g} / \mathrm{mol})$. The $\theta$ surface coverage calculated is equal to $74 \%$, close to the $66 \%$ value found previously in the same experimental conditions [12]. There is no frequency shift during circulation of a non complementary T1 target buffer solution $(3.2 \mu \mathrm{M}, \mathrm{NaCl} 0.5 \mathrm{M}, \mathrm{pH} 7.2)$, indicating that no non specific physical adsorption occurs. A - $83 \mathrm{~Hz}$ frequency decrease is recorded during circulation of a complementary target $\underline{\mathrm{T} 2}$ solution $(3.2 \mu \mathrm{M}, \mathrm{NaCl} 0.5 \mathrm{M}, \mathrm{pH} 7.2)$, indicating hybridization of the target with a complementary grafted probe. The hybridization is irreversible since there is no variation of frequency during circulation of a buffer solution $(\mathrm{NaCl} 0.5 \mathrm{M}, \mathrm{pH}$ 7.2). The hybridization efficiency $\lambda(\%)$ is equal to:

$$
\lambda=100 \cdot \Delta \underline{\mathrm{f}_{\mathrm{T}}} \cdot \mathrm{M}_{\mathrm{P}} / \Delta \mathrm{f}_{\mathrm{P}} \cdot \mathrm{M}_{\underline{\mathrm{T}} \underline{3}}
$$

$\Delta \mathrm{f}_{\mathrm{T} 3}$ is the frequency change during hybridization $(-83 \mathrm{~Hz})$ and $\mathrm{M}_{\mathrm{T} 3}$ the target $\mathrm{T} 3$ molecular weight $(6055 \mathrm{~g} / \mathrm{mol})$. The $\lambda$ hybridization efficiency calculated is equal to $41 \%$, close to the $45 \%$ value found previously in the same experimental conditions (Lazerges et al., 2005). Frequency change after circulation of an alkaline saline solution $(\mathrm{NaOH} 0.5 \mathrm{M}, \mathrm{NaCl} 3 \mathrm{M})$ $(82 \mathrm{~Hz})$ is opposite to hybridization frequency change $(-83 \mathrm{~Hz})$, demonstrating a successful removing of hybridized target from the biosensor surface. Repeating such hybridization and regeneration cycles are performed. Hybridization frequency change of target T3 is constant, equal to $62 \pm 6 \mathrm{~Hz}$. Regeneration of the biosensor is successful up to 60 cycles (Figure 3-B).

\subsection{Biosensor frequency-target length response}

Since biological layers deposited onto solid substrates can induce an energy loss of the quartz oscillation, we assess if there is a linear relation between frequency and mass changes. Hybridization runs of complementary targets of different length, from 10 to 45 bases (T2, T3, T4 and T6), are performed at 1.7 $\mu \mathrm{M}$ in HEPES (Figure 4-A). 

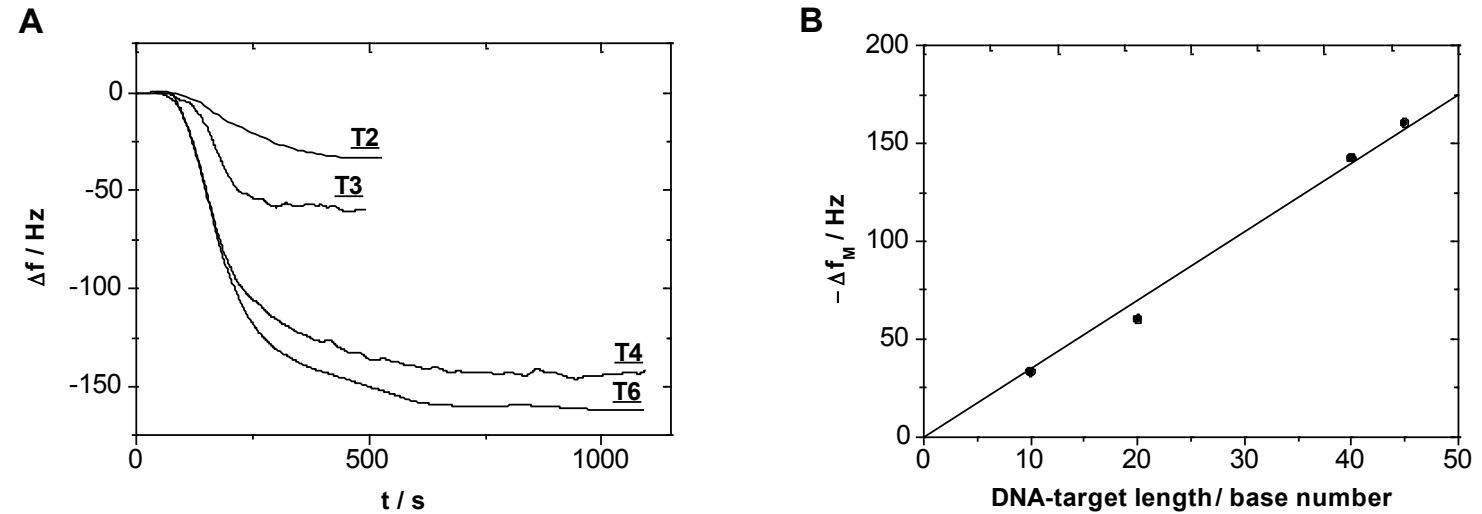

Figure 4. Hybridization frequency-time curves of complementary targets $\underline{\mathrm{T} 2}$ (10 bases), $\underline{\mathrm{T} 3}$ (20 bases), $\underline{\mathrm{T} 4}$ (40 bases) and $\underline{\mathrm{T} 6}$ (45 bases) (A). Hybridization frequency variation with complementary target length (B).

Frequency $\Delta \mathrm{f}_{\mathrm{M}}$ hybridization evolution with target length $\mathrm{n}$ is linear up to 45 bases (Figure 4B):

$$
-\Delta \mathrm{f}_{\mathrm{M}}=\mathrm{a} \cdot \mathrm{n}
$$

The linear coefficient a is equal to $3.5 \pm 0.1 \mathrm{~Hz} / \mathrm{base}\left(\mathrm{R}^{2}=0.997\right)$.

\subsection{Hybridization kinetics}

Hybridization kinetics of complementary 20-base target $\underline{\mathrm{T} 3}$ and 40-base target $\underline{\mathrm{T}} 4$ recorded at different concentrations are respectively presented on figure 5-A and 5-B. Normalized kinetics ratio of $\mathrm{T} 3$ and $\mathrm{T} 4,1-\Delta \mathrm{f} / \Delta \mathrm{f}_{\mathrm{M}}$, are respectively reported on figures $5-\mathrm{C}$ and $5-\mathrm{D}$ (logarithmic values).
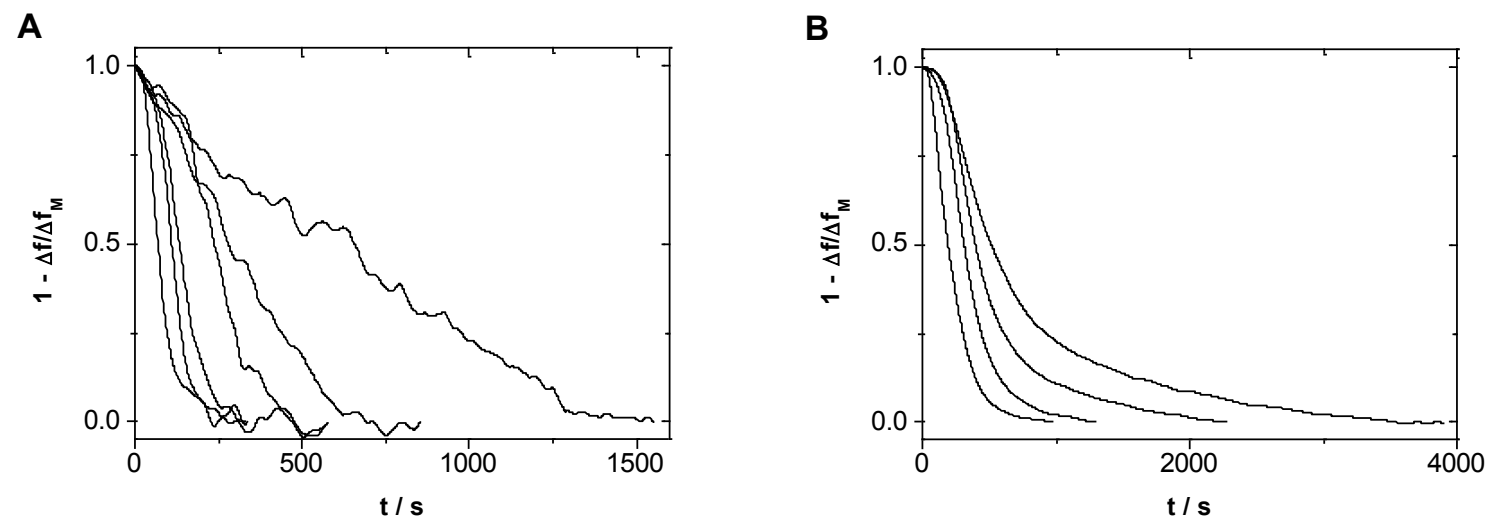

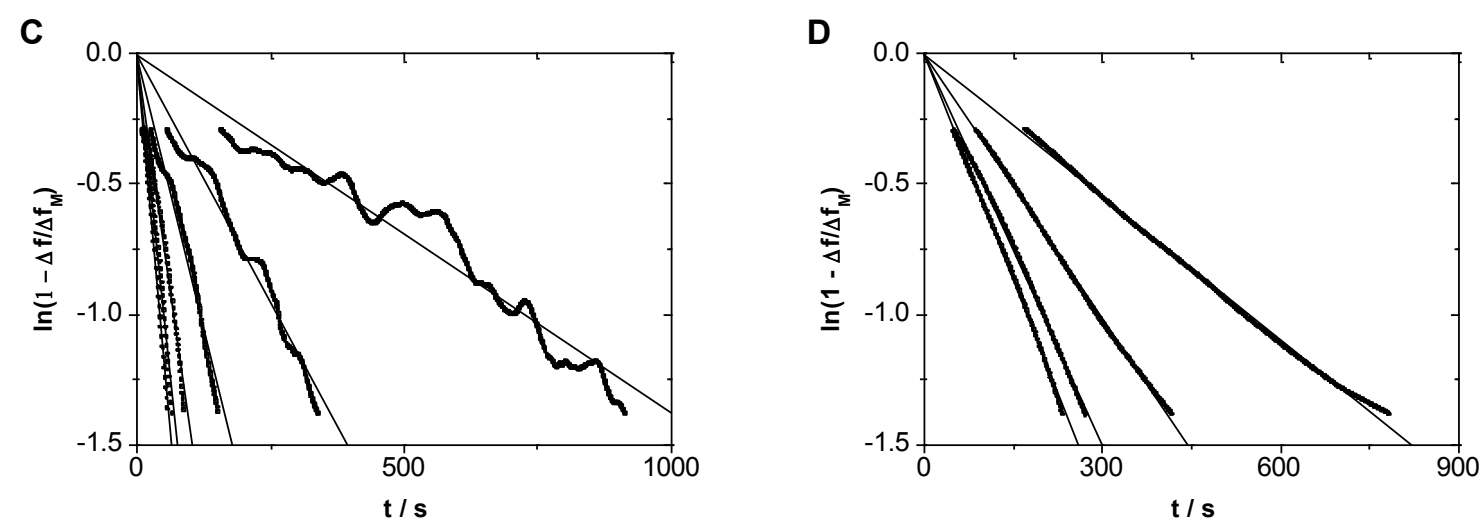

Figure 5. Hybridization kinetics curves: from left to right, normalized hybridization curves of complementary 20-base $\underline{\mathrm{T} 3}$ target at $3.3 \cdot 10^{-7}, 8.3 \cdot 10^{-7}, 3.3 \cdot 10^{-6}, 8.3 \cdot 10^{-6}, 1.7 \cdot 10^{-5}$ and $3.3 \cdot 10^{-5}$ $\mathrm{M}(\mathrm{A})$, and 40-base T4 target at $8.3 \cdot 10^{-7}, 1.7 \cdot 10^{-6}, 4.2 \cdot 10^{-6}$ and $8.3 \cdot 10^{-6} \mathrm{M}(\mathrm{B})$. Logarithmic hybridization curves of complementary 20-base T3 target (C) and 40-base T4 target (D).

Hybridization in an interfacial environment can be described by the first order adsorption kinetics law [E1], which is equal, in the case of frequency measurements, to:

$$
\ln \left(1-\Delta \mathrm{f} / \Delta \mathrm{f}_{\mathrm{M}}\right)=-\mathrm{k} . \mathrm{t}
$$

The experimental curves evolutions of $\ln \left(1-\Delta \mathrm{f} / \Delta \mathrm{f}_{\mathrm{M}}\right)$ are linear for both $\underline{\mathrm{T} 3}$ (Figure 5-C) and T4 (Figure 5D) targets all over the concentration range. Values of the kinetics constant $\mathrm{k}$ are calculated and reported on the table 2 .

$\underline{\mathrm{T} 3}$

\begin{tabular}{cccccccc}
\hline $\mathrm{C}_{\mathrm{DNA}}$ & $\mathrm{k}$ & $\Delta$ & $\mathrm{R}^{2}$ & $\mathrm{C}_{\mathrm{DNA}}$ & $\mathrm{k}$ & $\Delta$ & $\mathrm{R}^{2}$ \\
\hline $\mathrm{mol. \textrm {L } ^ { - 1 }}$ & \multicolumn{2}{c}{$\mathrm{s}^{-1}$} & & $\mathrm{mol. \textrm {L } ^ { - 1 }}$ & \multicolumn{2}{c}{$\mathrm{s}^{-1}$} & \\
\hline $3.3 \cdot 10^{-8}$ & $1.38 \cdot 10^{-3}$ & $1 \cdot 10^{-5}$ & 0.94 & $8.3 \cdot 10^{-8}$ & $1.83 \cdot 10^{-3}$ & $5 \cdot 10^{-6}$ & 0.998 \\
$8.3 \cdot 10^{-8}$ & $3.81 \cdot 10^{-3}$ & $4 \cdot 10^{-5}$ & 0.97 & $1.7 \cdot 10^{-7}$ & $3.39 \cdot 10^{-3}$ & $9 \cdot 10^{-6}$ & 0.999 \\
$3.3 \cdot 10^{-7}$ & $8.49 \cdot 10^{-3}$ & $1 \cdot 10^{-4}$ & 0.97 & $4.2 \cdot 10^{-7}$ & $5.01 \cdot 10^{-3}$ & $2 \cdot 10^{-5}$ & 0.998 \\
$8.3 \cdot 10^{-7}$ & $1.46 \cdot 10^{-2}$ & $2 \cdot 10^{-4}$ & 0.99 & $8.3 \cdot 10^{-7}$ & $5.79 \cdot 10^{-3}$ & $3 \cdot 10^{-5}$ & 0.998 \\
$1.7 \cdot 10^{-6}$ & $1.99 \cdot 10^{-3}$ & $5 \cdot 10^{-4}$ & 0.98 & & & & \\
$3.3 \cdot 10^{-6}$ & $2.32 \cdot 10^{-2}$ & $3 \cdot 10^{-4}$ & 0.99 & & & &
\end{tabular}

Table 2. First order rate kinetics constant $\mathrm{k}$ deduced from hybridization kinetics curves of complementary DNA targets $\underline{\mathrm{T} 3}$ and $\underline{\mathrm{T} 4}$.

The standard deviation on the $\mathrm{k}$ value is close to $1 \%$ for $\mathrm{T} 3$ target and close to $0.5 \%$ for $\mathrm{T} 4$ target, indicating that a first order adsorption kinetics law is well adapted to describe hybridization of both targets all over the concentration range. 


\section{Discussion}

The kinetics $\mathrm{k}$ value describes the overall hybridization kinetics behavior. Hybridization kinetics $\mathrm{k}$ versus target bulk solution concentration $\mathrm{C}$ is presented on figure $6-\mathrm{A}$. The experimental k-C curves (Figure 6-A) are not linear, indicating that hybridization curves can not be fitted using equation [2]. Therefore this mechanism can not be described with the onestep hybridization mechanism presented on figure $1 . \mathrm{k}$ reaches an horizontal limit at high concentration values. Considering this experimental observation, it is assumed that there is a saturation of the biosensor surface with hybridized probes at high bulk solution target concentrations.

A

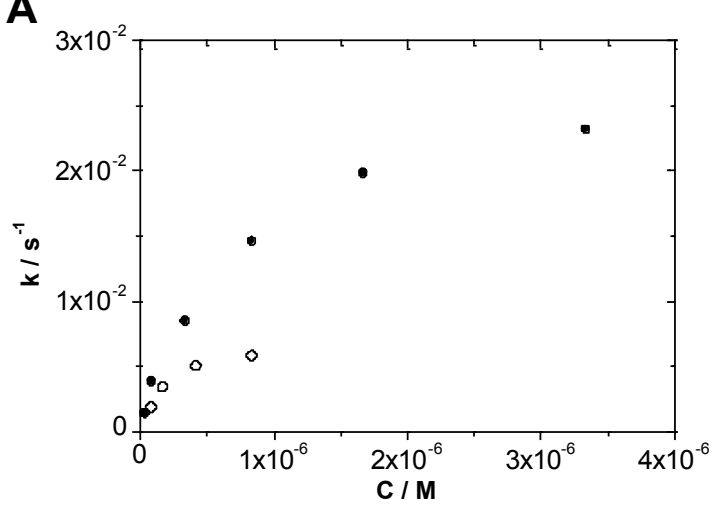

B

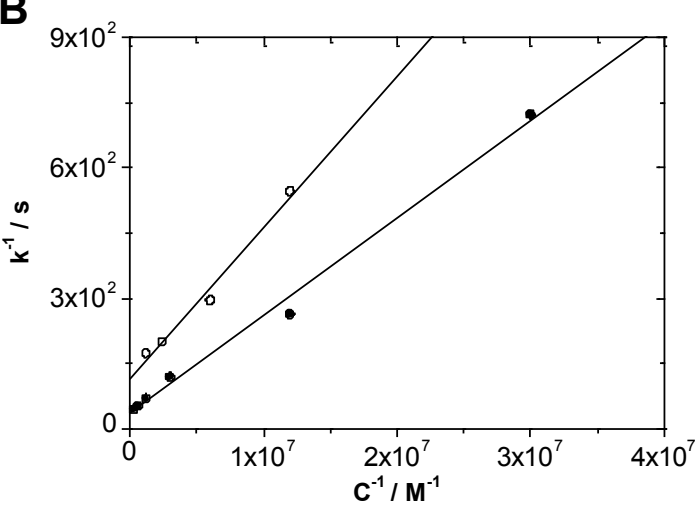

Figure 6. Curves $\mathrm{k}-\mathrm{C}(\mathrm{A})$ and $\mathrm{k}^{-1}-\mathrm{C}^{-1}(\mathrm{~B})$, for complementary DNA target $\underline{\mathrm{T}} 3$ (open circles) and $\underline{\mathrm{T} 4}$ (filled circles).

The equation [4], corresponding to a two-step mechanism (Figure 2), yield to a linear relationship [9] between $\mathrm{k}^{-1}$ and $\mathrm{C}^{-1}$ (Annexe):

$$
\mathrm{k}^{-1}=1 / \mathrm{k}_{2}+1 /\left(\mathrm{K}_{1} \cdot \mathrm{k}_{2}\right) \cdot \mathrm{C}^{-1}
$$

The experimental $\mathrm{k}^{-1}-\mathrm{C}^{-1}$ curves (Figure 6-B) are linear, indicating that hybridization can be described by such a two step mechanism. It is important to note that the widely used equation [E3] can be used to describe hybridization at low target concentration, as the k-C curves are linear at low concentration (figure 6-A). The linear fit correlation coefficients $\mathrm{R}^{2}$ are equal to 0.98 and 0.992 for respectively DNA targets $\underline{\mathrm{T} 3}$ and $\underline{\mathrm{T}} 4 . \mathrm{K}_{1}, \mathrm{k}_{2}$ and $\mathrm{k}_{\mathrm{eff}}$ values calculated from linear fits (Figure 6-B) are reported on the table 3.
DNA-target
$\mathrm{K}_{1} / \mathrm{M}^{-1}$
$\mathrm{k}_{2} / \mathrm{s}^{-1}$
$\mathrm{k}_{\mathrm{eff}} / \mathrm{M}^{-1} \cdot \mathrm{s}^{-1}$ 
Table 3. Kinetics constants $\mathrm{K}_{1}, \mathrm{k}_{2}$ and $\mathrm{k}_{\text {eff }}$ of the two-step DNA hybridization mechanism.

$\mathrm{K}_{1}$ coefficient is higher for the largest target $\underline{\mathrm{T}}$, indicating that adsorption increases with target size. $\mathrm{k}_{2}$ is higher for the taller target $\underline{\mathrm{T}}$, indicating that irreversible hybridization decreases with target size. It is interesting to point that $\mathrm{K}_{1}$ and $\mathrm{k}_{2}$ values depends drastically and in the opposite way on target size. $\mathrm{k}_{\mathrm{eff}}$, equal to the product $\mathrm{K}_{1} \cdot \mathrm{k}_{2}$ decreases with length, but it does not depend as drastically of target size like $\mathrm{K}_{1}$ et $\mathrm{k}_{2}$ does. This $\mathrm{k}_{\text {eff }}$ value, widely used to study target structural effects on nucleic acid hybridization in an interfacial environment [13], depends on both, adsorption and irreversible hybridization . A last question is addressed in this work: is adsorption equilibrium of a complementary target is affected by non specific adsorption of a non complementary target onto the biosensor surface ? In order to give a clear response, hybridization of the 45-base complementary target $\underline{\mathrm{T} 6}$ is performed with and without 20-base non complementary DNA T1 (Figure 7).

A

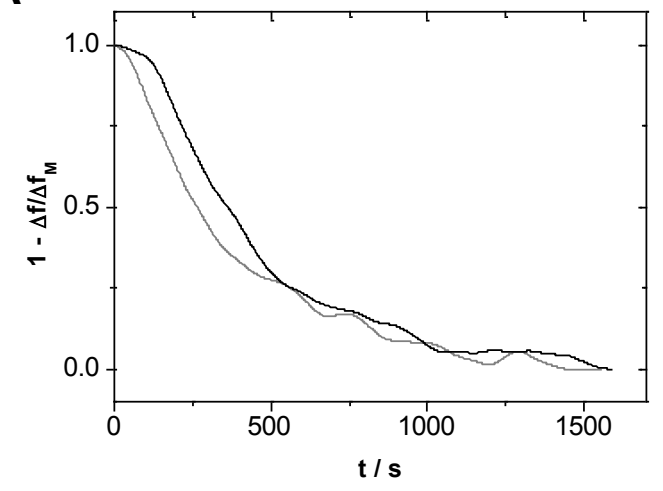

B

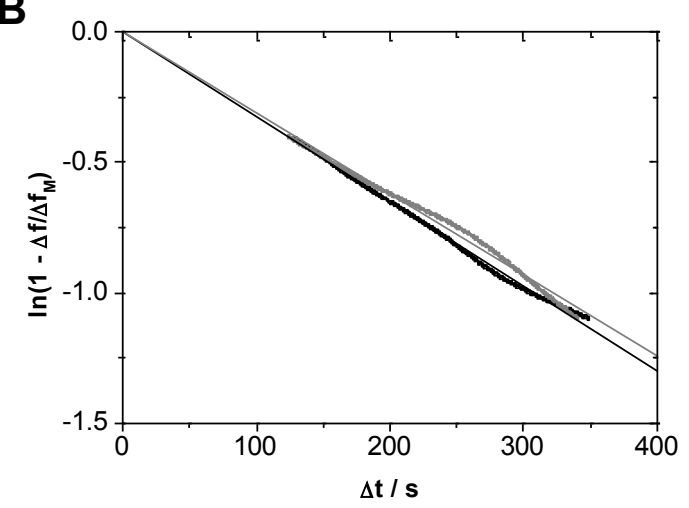

Figure 7. Hybridization kinetics decimal (A) and logarithmic (B) kinetics curves of $\underline{\mathrm{T}} 6$ complementary target $\left(1.5 .10^{-7} \mathrm{M}\right)$ without (black) and with (grey) non complementary target $\mathrm{T} 1\left(1.5 \cdot 10^{-6} \mathrm{M}\right)$.

Hybridization first order kinetics constant of $\underline{\mathrm{T}} 6$ with and without $\mathrm{T} 1$, respectively equal to $3.25 .10^{-3} \mathrm{~s}^{-1}$ and $3.10 .10^{-3} \mathrm{~s}^{-1}$, are close and consistants with kinetics reported on table 2. The fact that non complemenrary targets do not change overall hybridization kinetics response indicate that adsorption thermodynamic constant $\mathrm{K}_{1}$ is relevant to formation of an hybridized pre-complex in the sensor biolayer. It is interesting to conclude that an advanced hybrization mechanism, taking into account such a two-step mechanism and a multiple targets mechanism 
described elsewhere [3], has not already been assessed by experimentals results, and may constitute the next challenge.

\section{Conclusion}

The two-step hybridization mechanism, previously reported on fluorimetric sensor on singlewalled nanotubes, is also observed in this work on gold surface with an acoustic sensor: this mechanism is adapted to study interfacial hybridization for different types of biosensor architectures. It was shown that the widely use effective hybridization constant $\mathrm{k}_{\text {eff }}$ depends on both pre-complex thermodynamics constant $\mathrm{K}_{1}$ (ie DNA pre-complex stability) and hybridization kinetics constant $\mathrm{k}_{2}$ (ie DNA duplex formation rate). This study demonstrates that kinetics constant depends on DNA target concentration in bulk solution. This approach allows to establish relation between $\mathrm{K}_{1}$ and $\mathrm{k}_{2}$ with target length and target bulk solution concentration. A Such investigation provides a solid background to analysis properly DNAbiosensor kinetics responses.

\section{Annexe}

Hybridization kinetics in an interfacial environment can be fitted by a first order adsorption kinetics law, which is equal, in the case of frequency measurements, to:

$$
\ln \left(1-\Delta \mathrm{f} / \Delta \mathrm{f}_{\mathrm{M}}\right)=-\mathrm{k} . \mathrm{t}
$$

$\Delta \mathrm{f}(\mathrm{Hz})$ is the microbalance frequency, $\Delta \mathrm{f}_{\mathrm{M}}(\mathrm{Hz})$ the microbalance frequency change for complete hybridization of a target, $\mathrm{k}\left(\mathrm{s}^{-1}\right)$ the first order kinetics value ant $\mathrm{t}(\mathrm{s})$ the time. The first step of surface hybridization mechanism is reversible adsorption of a target on the biosensor surface, described by Langmuir equation:

$$
\mathrm{K}_{1}=\theta / \text { C. }(1-\theta)
$$

$\mathrm{K}_{1}\left(\mathrm{M}^{-1}\right)$ is the thermodynamic equilibrium constant, $\theta$ the adsorption ratio and $\mathrm{C}(\mathrm{M})$ the target bulk concentration. The second step of surface hybridization mechanism is irreversible hybridization of the target with a grafted probe. This step irreversible step is the rate determining step of overall hybridization process:

$$
\mathrm{d} \eta / \mathrm{dt}=-\mathrm{k}_{2} \cdot \theta \cdot \eta
$$


$\eta$ is the single stranded grafted probe surface ratio and $k_{2}$ the kinetics constant of the irreversible surface hybridization step. Integration of [A3], taking into account [A2], yield to:

$$
\eta=\exp \left(-\left(\mathrm{K}_{1} \cdot \mathrm{k}_{2} \cdot \mathrm{C} /\left(1+\mathrm{K}_{1} \cdot \mathrm{C}\right)\right) \mathrm{t}\right)
$$

Elsewhere, hybridization efficiency is equal to the ratio :

$$
\eta=\Delta \mathrm{f} / \Delta \mathrm{f}_{\mathrm{M}}
$$

Where $\Delta \mathrm{f}$ is hybridization frequency change and $\Delta \mathrm{f}_{\mathrm{M}}$ frequency change for complete hybridization. [A4] and [A5] yield to:

$$
\ln \left(1-\Delta \mathrm{f} / \Delta \mathrm{f}_{\mathrm{M}}\right)=-\left(\mathrm{K}_{1} \cdot \mathrm{k}_{2} \cdot \mathrm{C} /\left(1+\mathrm{K}_{1} \cdot \mathrm{C}\right)\right) \cdot \mathrm{t}
$$

[A1] and [A6] yield in fine to:

$$
\mathrm{k}=\mathrm{K}_{1} \cdot \mathrm{k}_{2} \cdot \mathrm{C} /\left(1+\mathrm{K}_{1} \cdot \mathrm{C}\right)
$$

\section{References}

[1] H. Su, M. Thomson, Kinetics of interfacial hybridization studied by acoustic network analysis, Biosens. Bioelectron. 10 (1995) 329-340.

[2] Y. Gao, L.K. Wolf, R.M. Georgiadis, Secondary structure effects on DNA hybridization kinetics: a solution versus surface comparison, Nucl. Acids Res. 34 (2006) 3370-3377.

[3] K. Tawa, W. Knoll, Mismatching base-pair dependance of the kinetics of DNA-DNA hybridization studied by surface plasmon fluorescence spectroscopy, Nucl. Acid Res. 32 (2004) 2372-2377.

[4] J. Zeng, A. Almadidy, J. Watterson, U.J. Krull, Interfacial hybridization kinetics of oligonucleotides immobilized onto fused silica surfaces, Sens. Actuators, B 90 (2003) 68-75.

[5] E.S. Jeng, P.W. Barone, J.D. Nelson, M.S. Strano, Hybridization kinetics and thermodynamics of adsorbed to individually dispersed single-walled carbon nanotubes, Small 3 (2007) 1602-1609.

[6] A. Atsushi, M. Akira, Production of oligonucleotide probe, Patent (1990) 63-19-1087.

[7] Y. Halim, Alexandrium minutum, n. gen. n. sp. dinoflagellé provocant des "eaux rouges", Vie et Milieu 11 (1960) 102-105. 
[8] L. Guillou, E. Nezan, E.,V. Cueff, F. Erard-Le Denn, M.A. Cambon-Bonavita, P. Gentien, , G. Barbier, Genetic diversity and molecular detection of three toxic dinoflagellate genera (Alexandrium, Dinophysis, and Karenia) from French coasts, Protist 153 (2002) 223-238.

[9] C.J. Bolch, S.I. Blackburn, J.A. Cannon, G.M. Hallegraeff, The resting cyst of the red-tide dinoflagellate Alexandrium minutum (Dinophyceae), Phycologia 30 (1991) 215-219.

[10] C.X. Zhou, L.Q. Huang, S.F.Y. Li, Microgravimetric DNA sensor based on quartz crystal microbalance: comparison of oligonucleotide immobilization methods and the application in genetic diagnosis, Biosens. Bioelectron. 16 (2001) 85-95.

[11] K. Bizet, C. Gabrielli, H. Perrot, Immunodetection by Quartz Crystal Microbalance, Appl. Biochem. Biotechnol 89 (2000) 139-150.

[12] M. Lazerges, H. Perrot, E. Antoine, A. Defontaine, C. Compere, Oligonucleotide quartz crystal microbalance sensor for the microalgae Alexandrium minutum (Dinophyceae), Biosens. Bioelectron. 21 (2006) 1355-1358.

[13] G. Yang, L.K. Wolf, R.M. Georgiadis,. Secondary structure effects on DNA hybridization kinetics: a solution versus surface comparison, Nucl. Acids Res. 34 (2006) 3370-3377. 